\title{
Comparison of Alkaline Treatment of Lead Contaminated Wastewater Using Lime and Sodium Hydroxide
}

\author{
Sudhakar M. Rao ${ }^{*}$, G. C. Raju ${ }^{2}$ \\ ${ }^{1}$ Department of Civil Engineering \& Chairman, Center for Sustainable Technologies, \\ Indian Institute of Science, Bangalore, India \\ ${ }^{2}$ Department of Civil Engineering, BMS College of Engineering, Bangalore, India \\ E-mail:msrao@civil.iisc.ernet.in \\ Received July 13, 2009; revised August 20, 2010; accepted August 26, 2010
}

\begin{abstract}
A lead-acid storage battery manufacturing industry in India produces several thousand liters of lead contaminated acidic wastewater on a daily basis and uses hydrated lime to render the lead-contaminated acidic wastewater alkaline $(\mathrm{pH}=8.0)$. Alkaline treatment of the acidic wastewater with lime though a cost-effective method, generates copious amount of lead-contaminated gypsum sludge. Other alkali agents such as sodium hydroxide, sodium carbonate and dolomite are also used for alkali treatment of the acid wastewaters. The present paper compares the relative efficiency of hydrated lime and $0.05 \mathrm{M}$ to $1 \mathrm{M} \mathrm{NaOH}$ solutions with respect to 1) amounts of sludge produced, 2) immobilization of the soluble lead in the acidic wastewater (AWW) and 3) increase in TDS (total dissolved solids) levels upon treatment of AWW with $\mathrm{NaOH}$ solutions and lime. The study also performs equilibrium speciation upon alkaline treatment of AWW with lime and $\mathrm{NaOH}$ (sodium hydroxide) solutions using the Visual MINTEQ program to understand the chemical reactions occurring during treatment process.
\end{abstract}

Keywords: Acid, Alkali Agents, Alkaline Treatment, Battery, Lead, Speciation, TDS

\section{Introduction}

A lead-acid storage battery manufacturing industry in India produces several thousand liters of lead contaminated acidic wastewater on a daily basis. The acidic wastewater (AWW) contains lead concentration of 4.24 $\mathrm{mg} / \mathrm{L}$ and has $\mathrm{pH}$ of 0.96 . Macchi et al. [1] report similar ranges of $\mathrm{pH}$ (1.6 and 2.9) but higher lead concentrations $(5-15 \mathrm{mg} / \mathrm{L})$ in acidic wastewaters of lead-acid storage battery units in Italy. Neutralization of the lead-contaminated acidic wastewaters are achieved by adjusting their $\mathrm{pH}$ values to a desirable range of 5.5 to 9.5 using alkaline agents such as, sodium hydroxide, sodium carbonate, lime and dolomite [2]. The lead-acid storage battery manufacturing industry in India uses hydrated lime to treat the lead-contaminated acidic wastewater to $\mathrm{pH}$ 8.0. Alkaline treatment of acidic wastewater by lime addition occurs according to the reaction:

$$
\mathrm{Ca}(\mathrm{OH})_{2}+\mathrm{H}_{2} \mathrm{SO}_{4} \rightarrow \mathrm{CaSO}_{4} \cdot 2 \mathrm{H}_{2} \mathrm{O}
$$

Alkaline treatment with lime also precipitates the soluble lead in the acidic wastewater as hydroxides, carbon- ates and sulfates that is incorporated in the gypsum sludge. Guided by the minimum solubility of lead compounds in the alkaline $\mathrm{pH}(8-10)$ range [3] the lead-acid battery manufacturing industry in India chose to treat their acidic wastewater to this $\mathrm{pH}(8.0)$.

Alkaline treatment of the acidic wastewater with lime though a cost-effective method, generates copious amount of sludge material. For example, calculations show that treatment of 1000 liters of acidic wastewater produces $100 \mathrm{~kg}$ of moist sludge. As mentioned earlier, $\mathrm{pH}$ of acidic wastewaters are also rendered alkaline by addition of sodium hydroxide, sodium carbonate, and dolomite [2]. Sodium hydroxide solution neutralizes the acidic wastewater according to the reaction:

$$
2 \mathrm{NaOH}+\mathrm{H}_{2} \mathrm{SO}_{4} \rightarrow \mathrm{Na}_{2} \mathrm{SO}_{4}+2 \mathrm{H}_{2} \mathrm{O}
$$

The advantage of employing sodium hydroxide solution is that the neutralization reaction (reaction 2) leads to minimum sludge formation as the reaction product $\mathrm{Na}_{2} \mathrm{SO}_{4}$ (sodium sulfate) is water-soluble. Macchi et al. [1] observe that neutralization of acidic battery wastewater using sodium hydroxide solution has an added advantage as the resident ferric ions in the battery 
wastewater precipitate (as hydroxides) and scavenge the lead ions from the wastewater. A possible disadvantage of neutralizing the acid wastewater with sodium hydroxide solution is an increase in total dissolved solids (TDS) concentration of the treated water owing to the formation of soluble sodium sulfate. Increase in TDS levels of the treated water is a concern as MOEF (Ministry of Environment and Forests) regulations [4] state that TDS levels of treated leachate for disposal on land or inland surface water bodies should not exceed $2100 \mathrm{mg} / \mathrm{L}$.

Earlier studies have not considered the relative impacts of lime and sodium hydroxide neutralization of lead-contaminated acidic wastewater on the amounts of sludge produced, lead removal efficiency and TDS levels of the treated wastewater. This paper hence compares the relative efficiency of lime and sodium hydroxide solutions with respect to 1) amounts of sludge produced upon alkaline treatment $(\mathrm{pH}=8)$ of $\mathrm{AWW}, 2)$ immobilization of available lead in AWW upon alkaline treatment and 3) increase in TDS levels of AWW upon alkaline treatment. Ion speciation studies are performed using the Visual MINTEQ program to obtain insight into changes in hydrogen ion concentration and equilibrium concentrations of aqueous and solid phases formed during the alkaline treatment process.

\section{Materials and Methods}

\subsection{Wastewater Sample and Chemicals}

Lead contaminated acidic wastewater (AWW) was supplied by the lead-acid battery industry in India. Laboratory reagent grade hydrated lime and sodium hydroxide were used in the AWW neutralization studies.

\subsection{Alkaline Treatment Assays}

The $\mathrm{pH}$ of the acidic wastewater was increased by adding incremental amounts of laboratory reagent grade hydrated lime to separate one-liter batches (of acid wastewater) with manual stirring until the $\mathrm{pH}$ of the wastewater stabilized for the given lime addition. Experimental results estimated that addition of $15.5 \mathrm{~g}$ of lime per liter of acidic wastewater altered its $\mathrm{pH}$ to 8.0 . The acidic wastewater was elevated to this $\mathrm{pH}$ to simulate the alkaline treatment process of the lead acid battery industry. To estimate the sludge generated by this lime addition process, a separate experiment was performed; $15.5 \mathrm{~g}$ of hydrated lime was added to one liter of acidic wastewater $(\mathrm{pH}=0.96)$. The lime-treated solution was filtered and analyzed for lead concentration using atomic absorption spectrophotometer. The resultant sludge was weighed in the moist condition.

The $\mathrm{pH}$ of the acidic wastewater was also increased by adding incremental amounts of 1 molar (M), 0.1 M and
$0.05 \mathrm{M} \mathrm{NaOH}$ solutions to separate, one-liter batches of AWW. The incremental volumetric additions were continued until the acidic wastewater was rendered sufficiently alkaline $(\mathrm{pH} 10.1$ to 10.7$)$. In separate experiments $0.405 \mathrm{~L}$ (liter), 3.78 L and $8.2 \mathrm{~L}$ of $1 \mathrm{M}, 0.1 \mathrm{M}$ and $0.05 \mathrm{M} \mathrm{NaOH}$ solutions were added to separate $1 \mathrm{~L}$ batches of acidic wastewater; the treated solutions were filtered and the resulting sludge were weighed in the moist condition. Lead concentrations in the filtrates were analyzed using atomic absorption spectrophotometer.

\subsection{Equilibrium Ion Speciation Estimation}

The study performed equilibrium speciation of AWW upon neutralization by lime and $\mathrm{NaOH}$ solutions using the Visual MINTEQ program [http://www.lwr.kth.se/ English/OurSoftware/vminteq/\#download]. Visual MINTEQ is a geochemical program to model aqueous solutions and the interactions of aqueous solutions with hypothesized assemblages of solid phases. It applies the fundamental principles of thermodynamics to solve geochemical equilibria from a set of mass balance equations. The input parameters to the Visual MINTEQ program were the chemical composition of AWW (Table 1), the $\mathrm{pH}$ of $\mathrm{AWW}$ on addition of lime or $1 \mathrm{M} \mathrm{NaOH}$ solution (Figure 1), mass of lime added (incorporated as solid finite phase) and increase in sodium ion concentration from addition of $1 \mathrm{M} \mathrm{NaOH}$ solution. Speciation of the lead by Visual MINTEQ program at various lime and 1 $\mathrm{M} \mathrm{NaOH}$ solution additions provided information on the relative amounts of lead occurring in the soluble and precipitated states during the treatment process.

\subsection{Analytical Methods}

Lead contaminated acidic wastewater (AWW) supplied by the lead-acid battery industry in India was filtered through 0.45 micron filter. The filtrate was analyzed for lead, iron, calcium, magnesium, sodium and potassium concentrations using atomic absorption spectrophotometer (model-Perkin Elmer Analyst 200). The concentration of, sulfate ions was determined by the turbidity method, while the chloride concentration was determined by ion

Table 1. Acidic wastewater composition.

\begin{tabular}{cc}
\hline Parameter & Value \\
\hline Lead $(\mathrm{mg} / \mathrm{L})$ & 4.24 \\
Iron $(\mathrm{mg} / \mathrm{L})$ & 80 \\
Calcium $(\mathrm{mg} / \mathrm{L})$ & 336 \\
Magnesium $(\mathrm{mg} / \mathrm{L})$ & 10.0 \\
Sodium $(\mathrm{mg} / \mathrm{L})$ & 195 \\
Potassium $(\mathrm{mg} / \mathrm{L})$ & 7 \\
Sulfate $(\mathrm{mg} / \mathrm{L})$ & 9100 \\
Chloride $(\mathrm{mg} / \mathrm{L})$ & 383 \\
$\mathrm{pH}$ & 0.96 \\
\hline
\end{tabular}


meter method using an ionmeter (Orion, 720A) with a chloride ion-selective electrode. The $\mathrm{pH}$ and electric conductivity of the acidic wastewater were also determined.

\section{Results and Discussion}

\subsection{Characteristic of Acidic Wastewater}

Table 1 presents the chemical composition of the acidic wastewater. The AWW has an acidic $\mathrm{pH}$ of 0.96 and soluble lead concentration of $4.24 \mathrm{mg} / \mathrm{l}$. The lead concentration of $4.24 \mathrm{mg} / \mathrm{l}$ in the acidic wastewater greatly exceeds the permissible limit $(0.1 \mathrm{mg} / \mathrm{l})$ for disposal of treated lead-acid battery effluent into the environment [5]. Besides, containing excess lead concentration, the acidic $\mathrm{pH}$ of the acidic wastewater (0.96) classifies the wastewater as a corrosive liquid [6]. High sulfate ion concentrations occur in the acidic wastewater of lead-acid storage battery units (Table 1), as sulfuric acid mainly constitutes the acidic wastewater. Soluble iron $(80 \mathrm{ppm})$ occurs in the acidic wastewater (Table 1) due to corrosion reactions [1]. Speciation by the Visual MINTEQ program indicated hydrogen ion concentration of 0.1096 $\mathrm{M}$ for the AWW which is expected for its $\mathrm{pH}$ value of 0.96 . Further, the speciation results show that bulk of the sulfate concentration in the AWW $(0.1 \mathrm{M})$ occurs as $\mathrm{HSO}_{4}^{-}(0.08 \mathrm{M})$ species.

\subsection{Lime Treatment of AWW}

Figure 1 presents the experimentally obtained plot of $\mathrm{OH}$

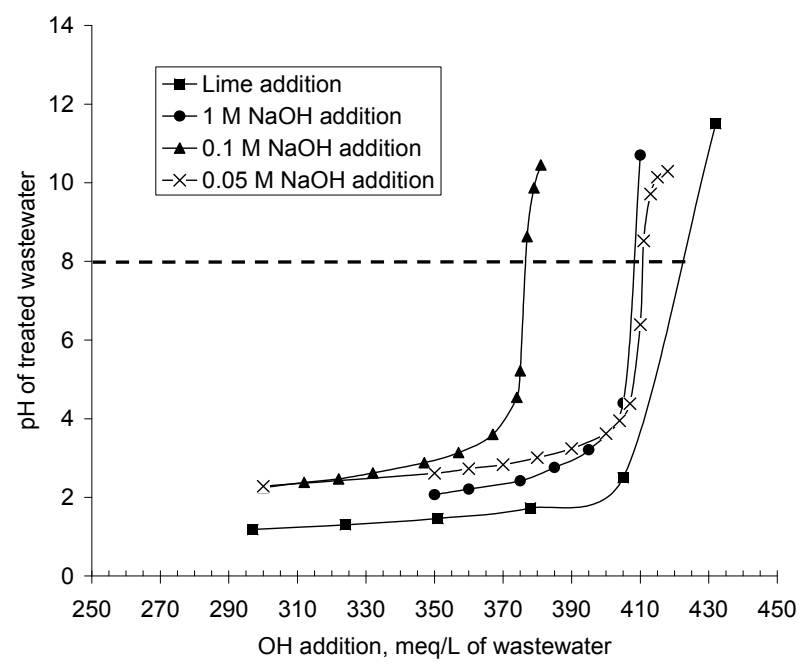

Figure 1. pH of acidic wastewater upon lime and $\mathrm{NaOH}$ solution addition.

addition (in meq/L) versus $\mathrm{pH}$ of AWW (Figure 1). The $\mathrm{OH}$ values in meq/L are obtained by converting mass of lime addition /L of AWW to equivalent $\mathrm{OH}$ concentration. The figure shows that hydroxyl ion additions up to 405 $\mathrm{meq} /$ liter marginally change the $\mathrm{pH}$ of the acidic wastewater. Increasing the hydroxyl ion concentration from 405 to $432 \mathrm{meq} / \mathrm{L}$ sharply increased the $\mathrm{pH}$ of AWW to 11.5. Addition of 422 meq of $\mathrm{OH}$ ions per liter of acidic wastewater is necessary to increase its $\mathrm{pH}$ to 8 (Figure 1). Alkaline treatment $(\mathrm{pH}=8)$ of 1 liter of $\mathrm{AWW}$ with hydrated lime generated $0.102 \mathrm{~kg}$ of moist sludge. The prominent peaks at $7.63 \AA, 4.28 \AA$ and $3.07 \AA$ in the X-ray diffraction of the air-dried (at $45{ }^{\circ} \mathrm{C}$ ) sludge (Figure 2)

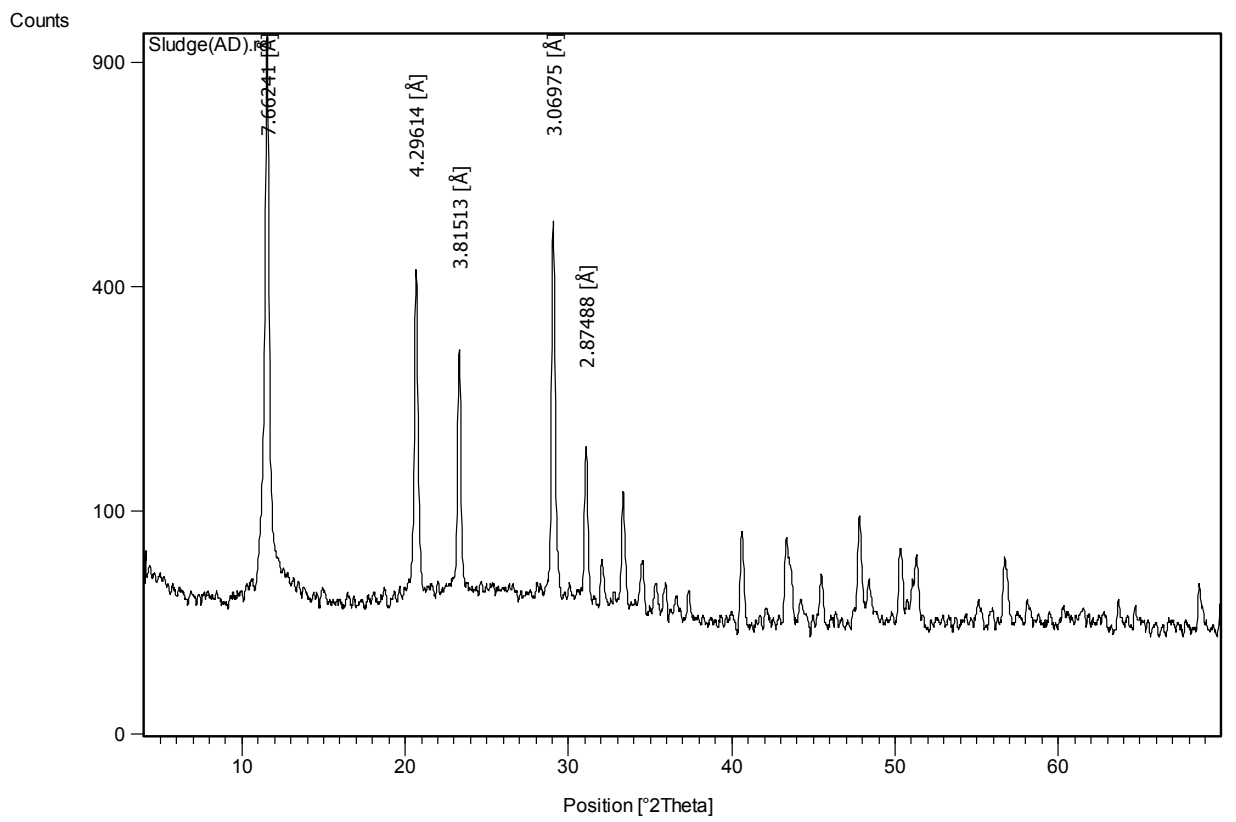

Figure 2. X-ray diffraction pattern of air-dried sludge. 
reveal the presence of gypsum mineral (calcium sulfate dihydrate, $\mathrm{CaSO}_{4} \cdot 2 \mathrm{H}_{2} \mathrm{O}$ ).

The speciation results show that alkaline treatment of AWW with lime reduces its initial hydrogen ion concentration from $0.1096 \mathrm{M}$ to $4.35 \times 10^{-12} \mathrm{M}$. Correspondingly the $\mathrm{HSO}_{4}{ }^{-}$concentration reduced from $0.08 \mathrm{M}$ to 2.25 $\times 10^{-13} \mathrm{M}$ and the calcium ion concentration increased from $0.074 \mathrm{M}$ to $0.16 \mathrm{M}$ (Figure 3). The increase in calcium ion concentration and reduction in hydrogen ion concentration upon lime treatment of AWW is explained
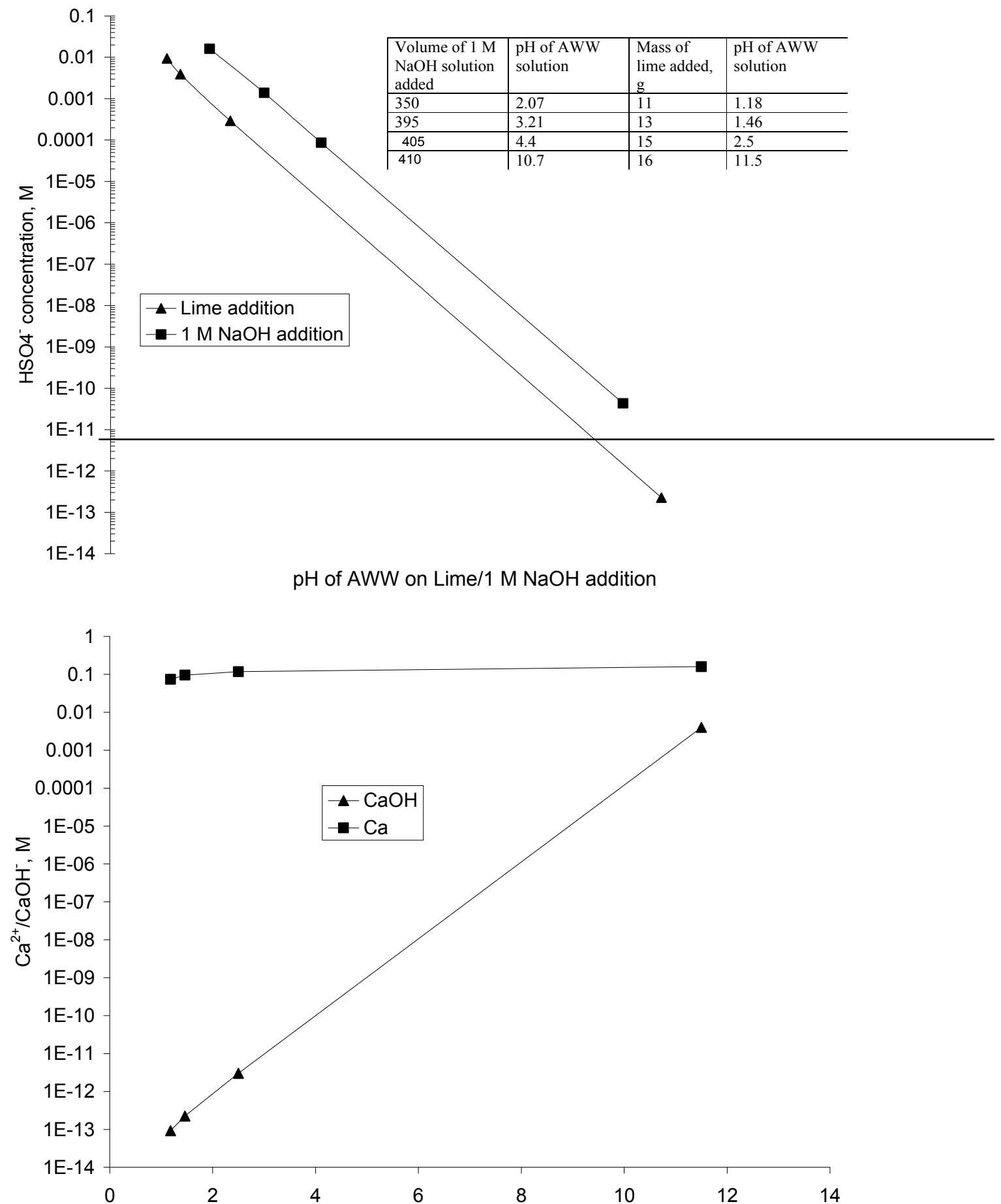

Figure 3. Variations in ion concentrations upon AWW neutralization with lime and 1 M NaOH solution-visual MINTEQ results. 
from the following reactions. Lime dissociates into calcium and hydroxyl ions (reaction 4); the dissociated hydroxyl ions reduce the hydrogen ions with the formation of $\mathrm{H}_{2} \mathrm{O}$ (reaction 5). Increasing addition of lime to AWW shifts the equilibrium to the right enhancing the hydroxyl ion concentration.

$$
\begin{gathered}
\mathrm{Ca}(\mathrm{OH})_{2} \leftrightarrow \mathrm{Ca}^{2+}+2 \mathrm{H}_{2} \mathrm{O}^{-} \\
2 \mathrm{OH}^{-}+2 \mathrm{H}^{+} \rightarrow 2 \mathrm{H}_{2} \mathrm{O}
\end{gathered}
$$

The sharp increase in $\mathrm{CaOH}$ - concentration (Figure 3) from $9.2 \times 10^{-14} \mathrm{M}$ at $\mathrm{pH} 1.18$ (lime addition $=11 \mathrm{~g} /$ liter) to $3.99 \times 10^{-3} \mathrm{M}$ at $\mathrm{pH} 11.5$ (lime addition $16 \mathrm{~g} / \mathrm{Liter}$ ) is attributed to the enhanced formation $\mathrm{CaOH}^{-}$in the strongly alkaline $\mathrm{pH}$ medium according to reaction:

$$
\mathrm{Ca}^{2+}+\mathrm{OH}^{-} \rightarrow \mathrm{CaOH}^{-}
$$

The speciation results show that the $\mathrm{HSO}_{4}{ }^{-}$concentration decreases from $0.009 \mathrm{M}$ to $2.25 \times 10^{-13}$ on increasing the $\mathrm{pH}$ of the AWW from 1.18 to 11.5 (Figure 3). Decrease in $\mathrm{HSO}_{4}{ }^{-}$concentration is attributed to the reduction of bisulfate to sulfate (reaction 7) and combination of calcium and sulfate ions to form $\mathrm{CaSO}_{4}(\mathrm{aq})$ :

$$
\begin{gathered}
\mathrm{HSO}_{4}{ }^{-}+\mathrm{OH}^{-} \rightarrow \mathrm{H}_{2} \mathrm{O}+\mathrm{SO}_{4}{ }^{2-} \\
\mathrm{Ca}^{2+}+\mathrm{SO}_{4}^{2-} \rightarrow \mathrm{CaSO}_{4} \text { (aq) }
\end{gathered}
$$

Speciation results showed that alkaline treatment $(\mathrm{pH}=8)$ of $\mathrm{AWW}$ with lime leads to the formation of $0.0052 \mathrm{M}$ to $0.0054 \mathrm{M} \mathrm{CaSO}_{4}$ (aq) species.
The lead ion concentration in lime-treated AWW $(\mathrm{pH}=8)$ correspond to $0.11 \mathrm{mg} / \mathrm{L}$ which marginally exceeds the permissible limit $(0.1 \mathrm{mg} / \mathrm{L})$ for disposal of treated effluent into environment [5]. The initial lead concentration in AWW corresponds to $4.24 \mathrm{mg} / \mathrm{L}$ or $2.046 \times 10^{-5} \mathrm{M}$. Speciation of the lead by Visual MINTEQ program at various lime additions provided information on the relative amounts of lead occurring in the soluble and precipitated forms during the lime treatment process. Figure 4 plots the soluble lead content as function of $\mathrm{pH}$ on lime addition. Lime addition up to 15 $\mathrm{g} / \mathrm{L}$ causes the entire lead to remain in soluble form $(\mathrm{pH}$ of treated effluent $=2.5$ ). Addition of $15.7 \mathrm{~g} / \mathrm{L}$ increases the AWW pH to 8 and causes near complete $(99.48 \%)$ precipitation of lead.

Figure 5 shows that $0.215 \mathrm{~kg}$ of moist sludge is generated upon alkaline treatment $(\mathrm{pH}=8)$ of AWW (volume $=1 \mathrm{~L}$ ) by lime addition. Figure 6 shows that the TDS level of lime-treated AWW (pH 8) corresponds to 2100 $\mathrm{mg} / \mathrm{L}$ which meets the TDS limit $(2100 \mathrm{mg} / \mathrm{L})$ recommended for disposal of treated leachate to land, inland surface water or public sewers [4].

\subsection{Sodium Hydroxide Treatment of Acidic Wastewater}

Figure 1 includes the experimentally obtained plots of $\mathrm{OH}$ addition (in $\mathrm{meq} / \mathrm{L}$ ) versus $\mathrm{pH}$ of $\mathrm{AWW}$ (Figure 1) for volumetric additions of $1 \mathrm{M}, 0.1 \mathrm{M}$ and $0.05 \mathrm{M}$

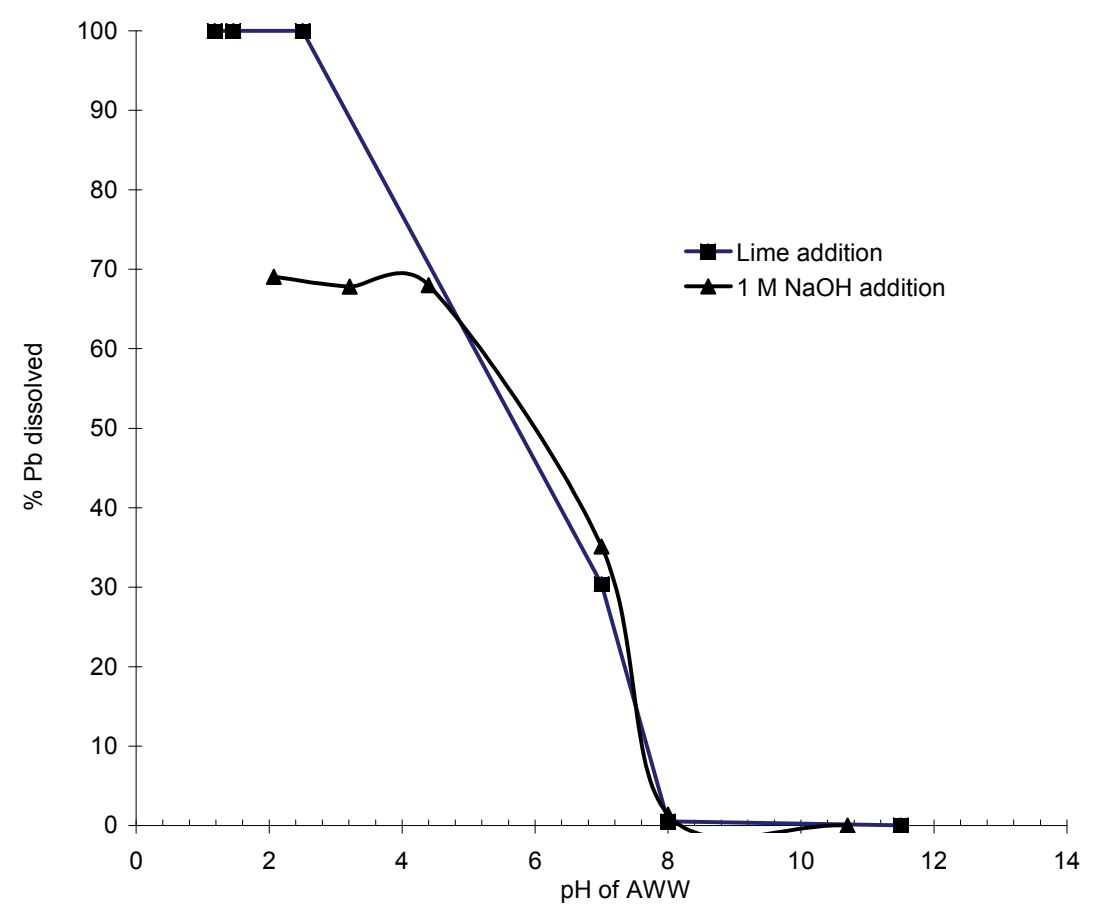

Figure 4. Variations of soluble lead concentrations as a function of pH upon AWW neutralization with lime and $1 \mathrm{M} \mathrm{NaOH}$ solution. 


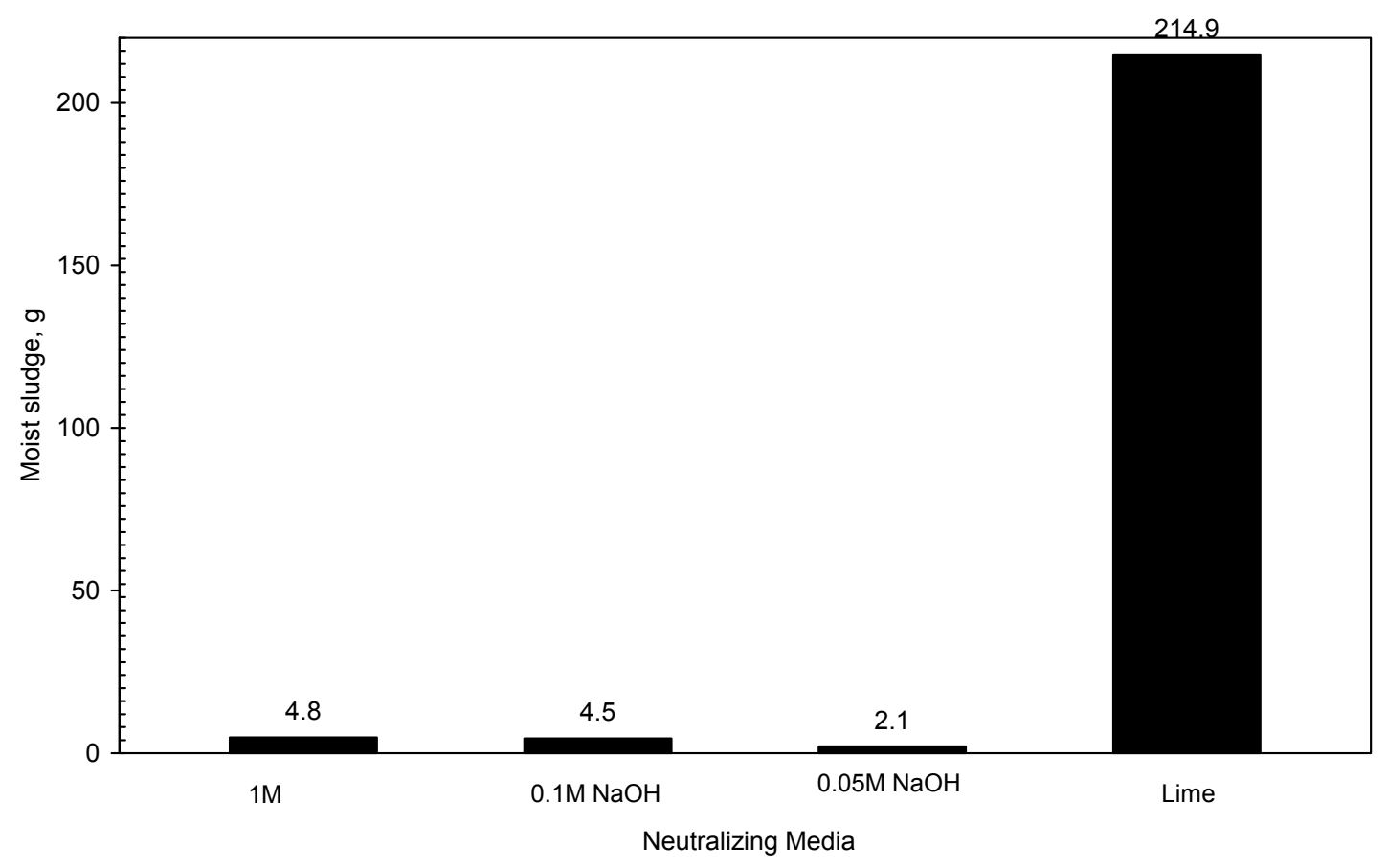

Figure 5. Comparison of moist sludge produced by different alkali agents.

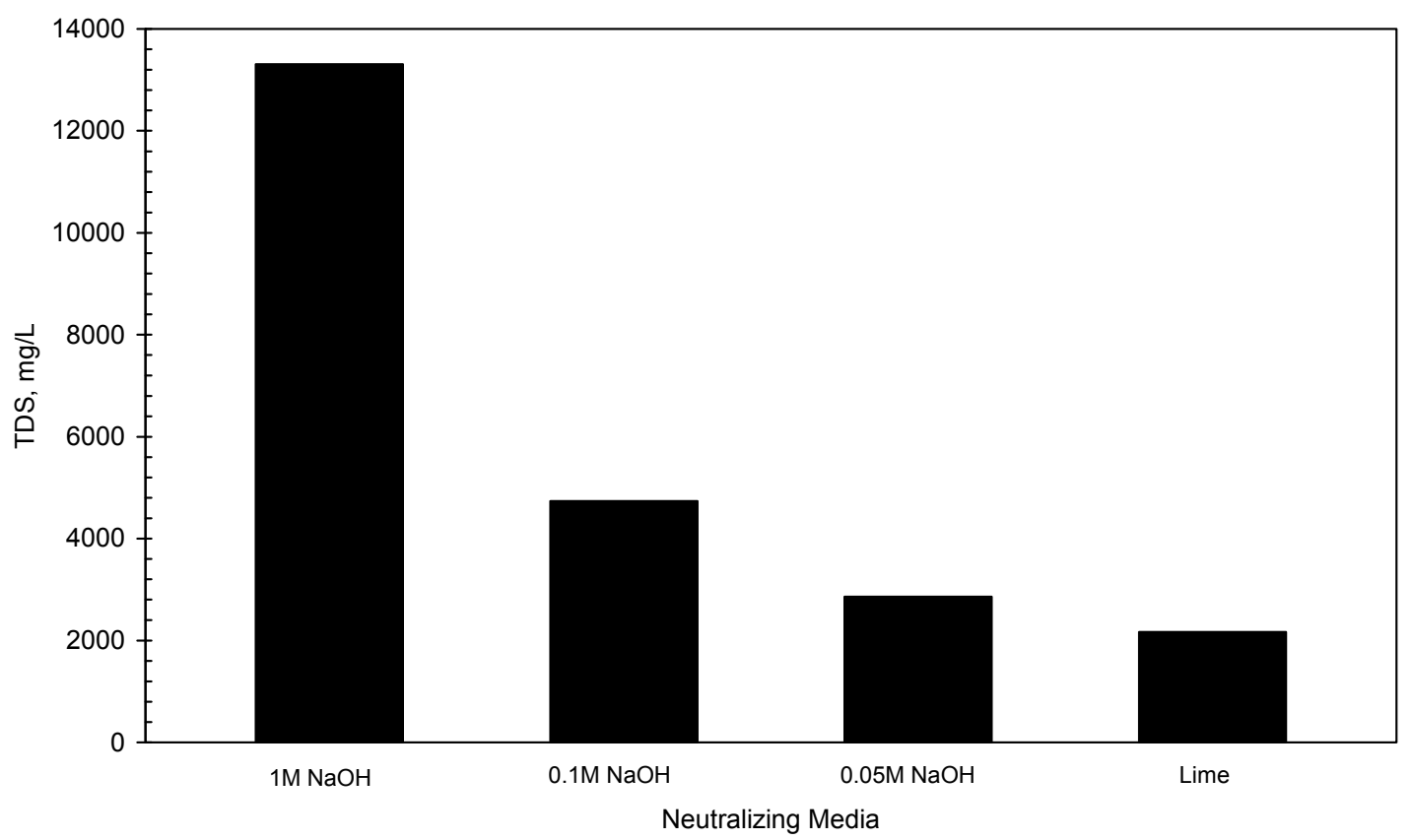

Figure 6. TDS levels in AWW neutralized with different alkali agents.

$\mathrm{NaOH}$ solutions. The figures show that the $\mathrm{pH}$ of the acidic wastewater responds to $\mathrm{NaOH}$ addition in two phases; the rate of increase in $\mathrm{pH}$ is gradual up to $\mathrm{pH}$ values of 3.6 to 4.4 ; thereafter rate of increase in $\mathrm{pH}$ with addition of $\mathrm{NaOH}$ solutions is a rapid process. These plots estimate that $407 \mathrm{meq} / \mathrm{L}, 377 \mathrm{meq} / \mathrm{L}$ and 410 meq/L of hydroxyl ions are required to modify the $\mathrm{pH}$ of the acidic wastewater from an initial value of 0.96 to desired value of 8.0 on addition of $1 \mathrm{M}, 0.1 \mathrm{M}$ and 0.05 $\mathrm{M} \mathrm{NaOH}$ solutions.

Visual MITEQ speciation results show that alkaline treatment $(\mathrm{pH}=8)$ of $\mathrm{AWW}$ with $1 \mathrm{M} \mathrm{NaOH}$ solution reduces the initial hydrogen ion concentration from $0.1096 \mathrm{M}$ to $2.72 \times 10^{-11} \mathrm{M}$ and the $\mathrm{HSO}_{4}{ }^{-}$concentration from $0.08 \mathrm{M}$ to $4.32 \times 10^{-11} \mathrm{M}$ (Figure 3); concomitantly, sodium ion concentration increases from $0.33 \mathrm{M}$ to 0.38 
M (Figure 7). The increase in sodium ion concentration and reduction in hydrogen ion concentration upon $\mathrm{NaOH}$ addition is attributed to the reactions:

$$
\begin{gathered}
\mathrm{NaOH} \rightarrow \mathrm{Na}^{+}+\mathrm{OH}^{-} \\
\mathrm{OH}^{-}+\mathrm{H}^{+} \rightarrow \mathrm{H}_{2} \mathrm{O}
\end{gathered}
$$

Speciation results show that the $\mathrm{HSO}_{4}{ }^{-}$concentration decreases from $0.016 \mathrm{M}$ to $4.31 \times 10^{-11} \mathrm{M}$ on increasing the $\mathrm{pH}$ of the AWW from 2.07 to 10.7 (Figure 3). The reduction in $\mathrm{HSO}_{4}{ }^{-}$concentration is attributed to the reaction:

$$
\mathrm{HSO}_{4}^{-}+\mathrm{Na}^{+}+\mathrm{OH}^{-} \rightarrow \mathrm{NaSO}_{4}^{-}+\mathrm{H}_{2} \mathrm{O}
$$

The concentration of $\mathrm{NaSO}_{4}{ }^{-}$species varies from 0.026 $\mathrm{M}$ at $\mathrm{pH} 2.07$ (350 $\mathrm{ml}$ addition) to $0.034 \mathrm{M}$ at $\mathrm{pH} 10.7$ (410 $\mathrm{ml}$ addition, Figure 7). Experimental measurements showed that the lead concentration in AWW treated with1 $\mathrm{M} \mathrm{NaOH}$ solution $(0.24 \mathrm{mg} / \mathrm{L})$ does not meet the permissible limit $(0.1 \mathrm{mg} / \mathrm{l})$ for disposal of treated effluent into inland surface water [5], while, AWW treated with $0.1 \mathrm{M}$ (lead concentration $=0.07 \mathrm{mg} / \mathrm{L})$ and $0.05 \mathrm{M}$ $\mathrm{NaOH}$ (lead concentration $=0.06 \mathrm{mg} / \mathrm{L}$ ) solutions meet this requirement. The inverse relation between concentration of sodium hydroxide solution and lead ion concentration in treated effluent is apparently related to volumes of the alkali solution used in the treatment process. Figure 1 had earlier estimated that $0.405 \mathrm{~L}, 3.78$
$\mathrm{L}$ and $8.2 \mathrm{~L}$ of $1 \mathrm{M}, 0.1 \mathrm{M}$ and $0.05 \mathrm{M} \mathrm{NaOH}$ solutions are required to modify the $\mathrm{pH}$ of the acidic wastewater from an initial value of 0.96 to desired value of 8.0. Smaller lead concentrations apparently occurs in the effluents treated with $0.1 \mathrm{M}$ and $0.05 \mathrm{M} \mathrm{NaOH}$ solutions owing to 9 to 20 times greater dilution of the acidic wastewater in comparison to treatment with $1 \mathrm{M} \mathrm{NaOH}$ solution. Visual MINTEQ results however did not show differences in the soluble/precipitated lead concentrations of $\mathrm{AWW}$ treated to $\mathrm{pH} 8$ with $1 \mathrm{M}, 0.1 \mathrm{M}$ and 0.05 $\mathrm{M} \mathrm{NaOH}$ solutions. The speciation results showed that identical levels $(98.7 \%)$ of lead precipitate $\left(\right.$ as $\mathrm{Pb}(\mathrm{OH})_{2}$, $\left.2.02 \times 10^{-5} \mathrm{M}\right)$ on treating the AWW to $\mathrm{pH} 8$ with the three $\mathrm{NaOH}$ solutions.

Figure 4 includes the Visual MINTEQ results for the soluble lead content (as a percentage) as function of $\mathrm{pH}$ on addition of $1 \mathrm{M} \mathrm{NaOH}$ solution. Treatment of AWW with $\mathrm{NaOH}$ solution renders significant fraction of lead insoluble (30 to $32 \%$ ) in the acidic $\mathrm{pH}$ range of 2.07 to 4.4 (Figure 4). Increasing the AWW pH to $8.0(408 \mathrm{ml}$ addition) rendered almost the entire lead fraction (98.7\%) insoluble. Figure 8 reveals that treating $\mathrm{AWW}$ with $\mathrm{NaOH}$ solution results in precipitation of $\mathrm{PbSO}_{4}$ species (anglesite) in the acidic pH range of 2.07 to 4.4 . The much larger equilibrium constant $\left(\log \mathrm{K}_{\mathrm{eq}}\right)$ for anglesite formation $\left(\log \mathrm{K}_{\mathrm{eq}}=7.79\right)$ in comparison to $\mathrm{Pb}(\mathrm{OH})_{2}$ formation $\left(\log \mathrm{K}_{\mathrm{eq}}=-8\right)$ is apparently responsible for precipitation of lead in the acidic $\mathrm{pH}$ range.

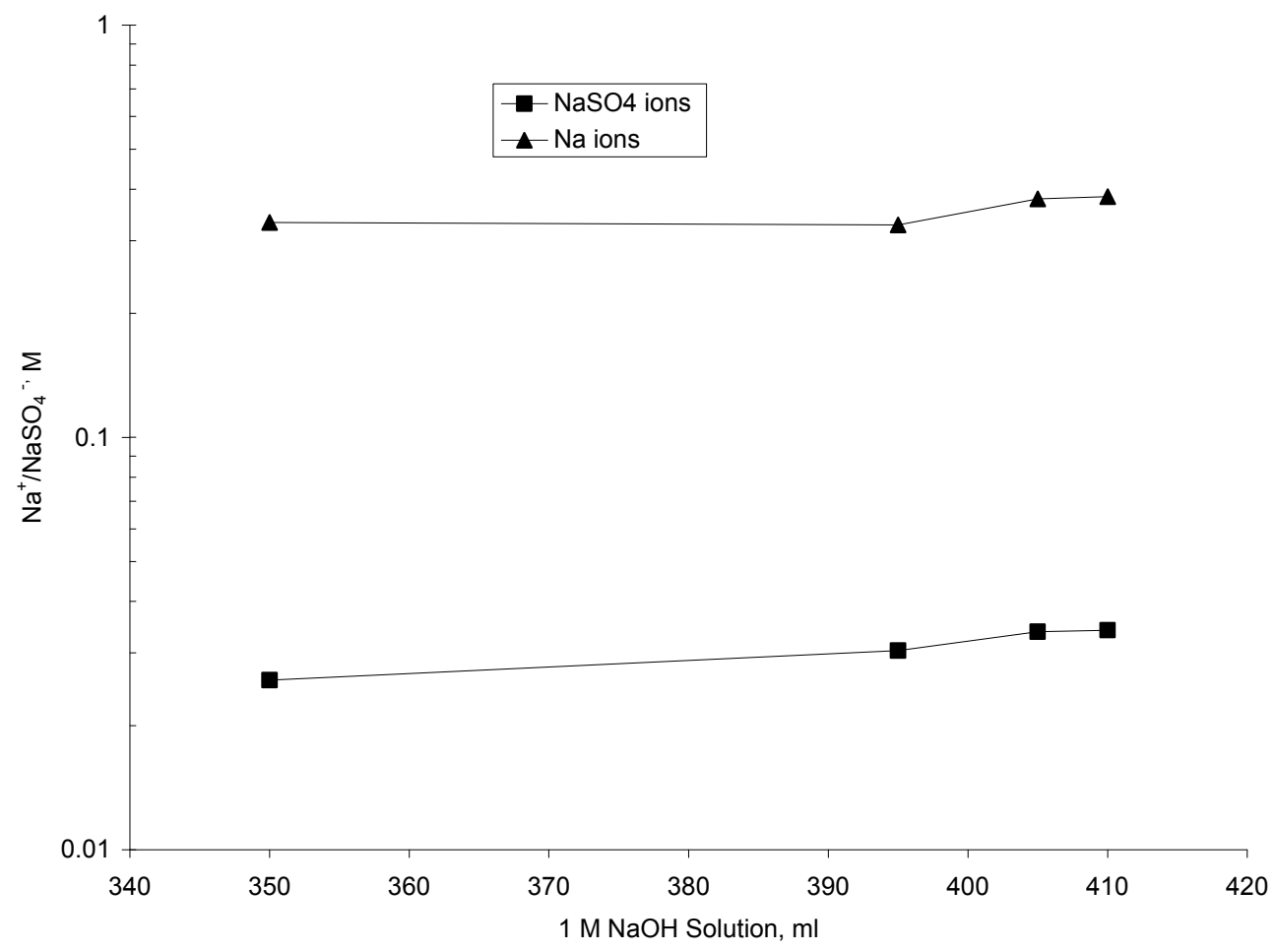

Figure 7. Variations in $\mathrm{Na}^{+}$and $\mathrm{NaSO}_{4}^{-}$ion concentrations upon AWW neutralization with 1 M NaOH solution-visual MINTEQ results. 


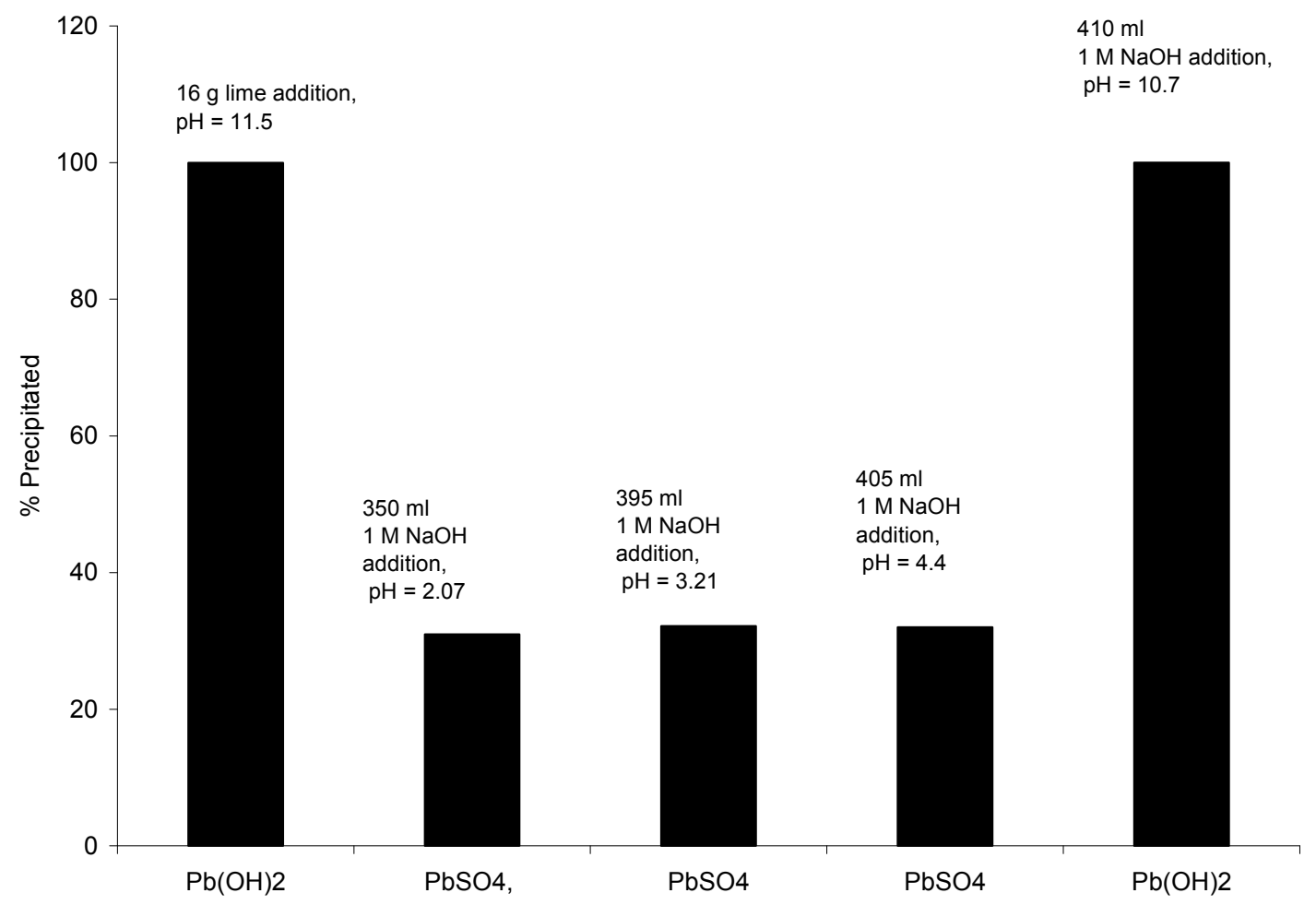

Figure 8. Relative distribution of precipitated lead as a function of $\mathrm{pH}$ upon $\mathrm{AWW}$ neutralization with lime and $1 \mathrm{M} \mathrm{NaOH}$ solution.

Figure 5 reveals that alkaline treatment of AWW $(\mathrm{pH}$ 8) with $0.05 \mathrm{M}, 0.1 \mathrm{M}$ and $1 \mathrm{M} \mathrm{NaOH}$ solutions produce $0.0021 \mathrm{~kg}, 0.0045 \mathrm{~kg}$ and $0.0048 \mathrm{~kg}$ of moist sludge respectively. Figure 6 compares the total dissolved solid concentration (TDS) of AWW treated to $\mathrm{pH} 8$ with $1 \mathrm{M}$, $0.1 \mathrm{M}, 0.05 \mathrm{M} \mathrm{NaOH}$ solutions respectively. Expectedly, the acidic wastewater treated with $1 \mathrm{M} \mathrm{NaOH}$ solution exhibits maximum TDS level of $13,310 \mathrm{mg} / \mathrm{L}$; the acidic wastewater treated with $0.05 \mathrm{M} \mathrm{NaOH}$ solution exhibits the minimum TDS level $(2800 \mathrm{mg} / \mathrm{L})$ which is higher than TDS limit recommended [4] for disposal of treated leachate to land, inland surface water or public sewers $(2100 \mathrm{mg} / \mathrm{L})$.

\subsection{Comparison of Lime and Sodium Hydroxide Treatments}

Figure 1 reveals that $\mathrm{NaOH}$ solutions are more effective than lime for alkaline treatment of $\mathrm{AWW}$ as the $\mathrm{pH}$ of the acidic wastewater is modified to 8.0 at lower $\mathrm{OH}$ concentrations (377 to $410 \mathrm{meq} / \mathrm{L}$ ) on addition of $\mathrm{NaOH}$ solutions than on lime addition $(\mathrm{OH}$ concentration $=422$ $\mathrm{meq} / \mathrm{L}$ at $\mathrm{pH}=8$ ). Experimental results in Figure 5 show that treatment with $\mathrm{NaOH}$ solutions produce much lesser (45 to 103 folds) masses of moist sludge than lime. Alkaline treatment $(\mathrm{pH} 8)$ with $0.1 \mathrm{M}$ and $0.05 \mathrm{M} \mathrm{NaOH}$ solutions generate acceptable levels of residual lead concentrations $(<0.1 \mathrm{mg} / \mathrm{L})$ in the treated AWW, while lime treatment results in residual lead concentration $(0.11 \mathrm{mg} / \mathrm{L})$ which is slightly in excess of the permissible limit. The disadvantage of using $\mathrm{NaOH}$ solutions is that the treated wastewater is characterized by higher total dissolved salt concentrations (2860 to $13310 \mathrm{mg} / \mathrm{L}$, Figure 6). For example, acidic wastewater treated with 0.05 $\mathrm{M} \mathrm{NaOH}$ solution has $33 \%$ higher TDS (TDS=2860 $\mathrm{mg} / \mathrm{L}$ ) than the sample treated with lime (TDS $=2100$ $\mathrm{mg} / \mathrm{L})$.

\section{Conclusions}

Speciation results showed that AWW is characterized by the presence of 0.196 molar $\mathrm{H}^{+}$and 0.08 molar $\mathrm{HSO}_{4}^{-}$ ion concentrations. Upon lime $/ \mathrm{NaOH}$ treatment, hydroxyl ions released by alkali dissociation, reduce hydrogen ions to form $\mathrm{H}_{2} \mathrm{O}$ molecules. Decrease in $\mathrm{HSO}_{4}{ }^{-}$ concentration is attributed to the reduction of bisulfate to sulfate ions; the sulfate ions combine with calcium/sodium ions to form $\mathrm{CaSO}_{4}(\mathrm{aq}) / \mathrm{NaSO}_{4}{ }^{-}$species. AWW is characterized by lead concentration of 4.24 $\mathrm{mg} / \mathrm{L}$. Speciation results showed that almost the entire lead fraction is precipitated (98.7 to $99.48 \%$ ) upon increasing the $\mathrm{pH}$ of $\mathrm{AWW}$ to 8.0 with lime or $1 \mathrm{M} \mathrm{NaOH}$ solution. Treating AWW with $0.1 \mathrm{M}$ and $0.05 \mathrm{M} \mathrm{NaOH}$ solutions generated acceptable residual lead concentra- 
tions (lower than the permissible limit of $0.1 \mathrm{mg} / \mathrm{L}$ ) in the treated wastewater owing to greater dilution of AWW by the weaker alkali solutions.

Comparison of $\mathrm{NaOH}$ and lime treatments reveal that lower $\mathrm{OH}$ concentrations (in $\mathrm{meq} / \mathrm{L}$ ) are required to modify the $\mathrm{pH}$ of AWW from 0.96 to 8.0. Further, smaller mass of moist sludge and environmentally acceptable levels of residual lead concentrations (for additions of $0.1 \mathrm{M}$ and $0.05 \mathrm{M}$ solutions) are generated upon $\mathrm{NaOH}$ treatment in comparison to lime treatment of AWW. Based on the minimal mass of moist sludge produced, acceptable residual lead concentration and lowest (among NaOH solutions) TDS of treated AWW, $0.05 \mathrm{M}$ $\mathrm{NaOH}$ solution is suggested as an alternative agent to remediate the acidic wastewater from lead-acid battery manufacturing industry. The treated AWW will however have to be subjected to some form of desalination before it is discharged on land or to inland water bodies to meet environmental norms for discharge of treated effluent into the environment.

\section{References}

[1] G. Macchi, M. Pagang, M. Santori, and G. Tiravanti, "Battery industrial wastewater: $\mathrm{Pb}$ removal and produced sludge,” Water Research, Vol. 27, pp. 1511-1518, 1993.

[2] J. W. Patterson, "Lead in wastewater treatment technology," Ann Arbor Science, Ann Arbor, Michigan, pp. 129-138, 1975.

[3] R. M. Harrisom and D. P. H. Laxen, "Lead pollution causes and control," Chapman and Hall, London, 1981.

[4] Ministry of Environment and Forests. Municipal Solid Wastes (Management and Handling) Rules 2000. MOEF, New Delhi, 2000.

[5] "Liquid effluent discharge standards for lead acid battery manufacturing," Central Pollution Control Board. http:// cpcb.nic.in.

[6] CPCB. "Guidelines for proper functioning and upkeep of disposal sites," Hazardous Waste Management Series: HAZWAMS/32/2005-2006, Central Pollution Control Board (CPCB), New Delhi, 2005. 